Uludag Univ. J. Fac. Vet. Med.

33 (2014), 1,2: 27-31

\title{
Kanatlı Hayvanların Rasyonlarında Fitaz Enzimi Kullanılmasının Önemi
}

\author{
Gülay DENIZ*
}

Geliş Tarihi: 02.04.2014

Kabul Tarihi: 21.05.2014

\begin{abstract}
Özet: Bilindiği gibi kanatlı hayvanların rasyonları büyük ölçüde bitkisel kökenli yem maddelerinden oluşmaktadır. Bu yem maddelerindeki toplam fosforun önemli bir kısmı kanatlılar tarafından yeterince yararlanılamayan fitik asite bağlı fitat fosforu formundadır. Bitkisel kökenli yem maddelerindeki fitik asit; fosfor dışındaki diğer mineral maddeler, nişasta, protein ve proteolitik enzimlerle de kompleks oluşturmaktadır. Kanatlı hayvanların rasyonlarına fitaz enzimi ilave edilerek; fitik asite bağlı fosfor, kalsiyum ve çinko gibi mineral maddeler ile protein, amino asitler ve nişasta sindirilebilirliğinde artış sağlanmaktadır. Rasyona fitaz enzimi ilavesiyle besin maddelerinin sindirilebilirliğinde meydana gelen bu artışlar, kanatlı hayvanların performansında iyileşmeye yol açmaktadır. Ayrıca mineral maddelerin biyoyararlanımlarının artmasıyla gübredeki düzeyleri azalmakta ve böylece çevre kirliliğinin önlenmesine katkıda bulunulmaktadır.
\end{abstract}

Anahtar Kelimeler: Kanatlı hayvanlar, fitik asit, fitat fosforu, fitaz enzimi.

\section{Significance of Using Phytase Enzyme in Poultry Ration}

\begin{abstract}
Poultry rations mostly consist of plant derived feedstuffs as known. Major portion of total phosphorous in these feedstuffs is form of phytase phosphorous combined with phytic acid which is less available for poultry. Phytic acid in plant derived feedstuffs also creates a complex with other minerals except phosphorus, starch, protein and proteolitic enzymes. Supplementation of phytase enzyme in poultry rations improve the digestibility of phosphorous combined with phytic acid, minerals such as calcium and zinc, protein, amino acids and starch. The improvement of nutrient digestibility by supplementation phytase enzyme to the ration increases the performance of poultry. The levels of minerals in the poultry litter decrease by improvement of mineral bioavailability which contribute to the prevention of environmental pollution.
\end{abstract}

Key Words: Poultry, phytic acid, phytate phosphororous, phytase enzyme.

\section{Giriş}

Fosfor kanatl1 rasyonlarına maliyet getiren bir besin maddesi olup, fosforun etkin bir şekilde kullanılması ekonomik kanatlı üretiminin vazgeçilmez unsurlarındandır. İskelet sisteminin gelişimi, kemik bütünlüğü, yumurta verimi ve yumurta kabuk kalitesinin sürdürülmesinin yan1 sira protein ve enerji metabolizmalarında da görev alan fosfor kanatlı hayvanların beslenmesinde önemli bir yere sahiptir. Bilindiği gibi kanatlı hayvanların rasyonları büyük oranda tahıl ve küspeler gibi bitkisel kökenli yem maddelerinden oluşmaktadır. Bitkisel kökenli yem maddelerindeki toplam fosforun yaklaşık olarak üçte ikisi fitik asite bağlanmış olan fitat fosforu şeklindedir ${ }^{15}$. Fitatlar (myo-inositol hekzafosfat), bitkisel kökenli yem maddelerinde fosforun başlica depolanma şeklidir. Kanatlı hayvanların fitat fosforunu hidrolize eden endo-

* U.Ü. Veteriner Fakültesi, Hayvan Besleme ve Beslenme Hastalıkları Anabilim Dalı, Bursa. denizg@uludag.edu.tr 
jen fitaz enzimini üretme yetenekleri oldukça düşük olduğundan ${ }^{12}$, bitkisel kökenli yem maddelerindeki fosfordan yeterince yararlanamazlar. Konuya ilişkin çalışmalarda; kanatlı hayvanlarda fitat fosforundan yararlanma oranının \% 3-42 arasında değişkenlik gösterdiği saptanmıştır ${ }^{23}$. $\mathrm{Bu}$ bağlamda fitat fosforunun kanatlı hayvanlar tarafindan yararlanılamayan kısmı gübre ile dışarı atılmaktadır. Topraktaki mikroorganizmalar gübredeki fitatları parçalayarak fosforu toprağa serbest bırakmaktadır. Bu durum gerek yer altı gerekse yer üstü sularının fosfor bakımından zenginleşmesine ve sonuç olarak su kirliliğine yol açmaktadır. Ayrıca, fitik asite bağlı fosforun kanatlı hayvanlar tarafından değerlendirilememesi, rasyona dikalsiyum fosfor (DCP) gibi pahalı inorganik fosfor kaynaklarının ilavesini zorunlu kılarak üretim maliyetlerinin artmasına neden olmaktadır. Fitik asitin fosfor dışında; başta bakır ve çinko olmak üzere kobalt, mangan, demir, kalsiyum ve magnezyum gibi birçok mineral maddeye karşı güçlü bir affinitesi bulunmaktadır. Yukarıda adı geçen mineral maddeler ile nötral pH'da çözünmeyen tuzlar meydana getiren fitik asit, kanatl hayvanların bu minerallerden yararlanmasina engel olmaktadır. Gübre ile dışarı atılan fitat fosforunun yanı sıra fitik asite bağlı çinko ve bakır gibi bazı iz minerallerin gübredeki düzeyleri de çevre kirliliği açısından sorun yaratmaktadır. Fitik asit ayrıca proteinler ve protein sindiriminde görev yapan proteolitik enzimlerle de (pepsin ve tiripsin) kompleksler yaparak, proteinlerden yararlanmay1 olumsuz yönde etkilemektedir. Fitik asitin bir diğer olumsuz etkisi ise yem maddelerindeki karbonhidratlarla kompleks oluşturarak yemin metabolik enerjisinde azalmaya yol açmasıdır. Yemin metabolik enerjisinin azalmasında, fitik asitin kalsiyumu bağlamak suretiyle nişasta sindiriminde görev alan alfa-amilaz enziminin aktivasyonunu azaltması da etkili olmaktadır. Fitik asit yukarıda bahsedilen bütün bu olumsuz etkilerinden dolayı kanatlı hayvanlar için bir antinutrisyonel faktör olarak kabul edilmektedir. Şekil 1'de fitat-protein-nişasta kompleksinin yapısı görülmektedir ${ }^{10}$. Fitik asitin gerek kanatlı performansında gerekse yem maliyeti ve çevre üzerinde oluşturduğu olumsuz etkiler, ekzojen fitazların kanatlı rasyonlarına ilavesiyle bir ölçüye kadar giderilebilmektedir ${ }^{22}$. Ancak ekzojen fitazların yanı sıra kanatlı hayvanların fitat fosforundan yararlanmasını etkileyen daha birçok faktör bulunmaktadır. Bu faktörler aşağıda kısaca özetlenmiştir.

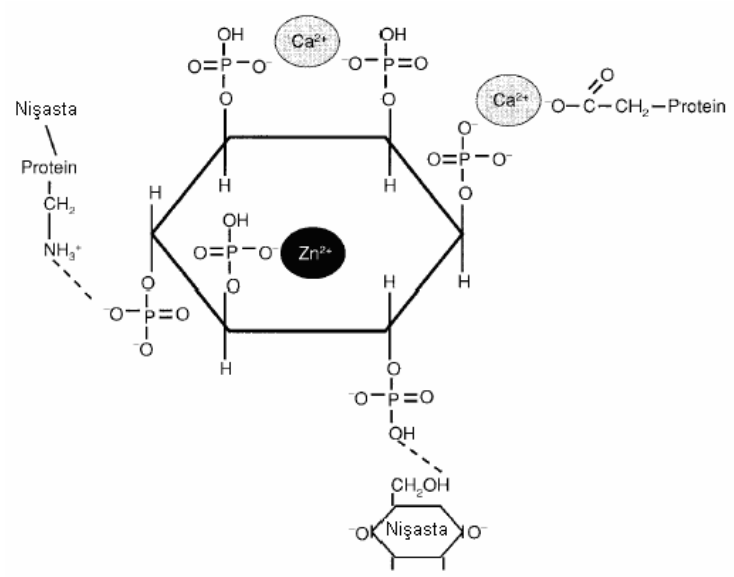

Şekil 1. Fitat-Protein-Nişasta Kompleksinin Yapısl (Kies, 2001).

\section{Kanatlı Hayvanların Fitat Fosforun- dan Yararlanmasını Etkileyen Faktörler}

1. Genotip: Genotip kanatlı hayvanlarda fitat fosforundan yararlanmay1 etkileyen en önemli faktörlerden birisidir. Yumurtacı tavuklar broylerlere göre rasyondaki fitat fosforundan daha iyi yararlanırlar ${ }^{7}$. Ayrıca broylerlerde irklara göre de fitat fosforundan yararlanmada farklılıklar bulunmaktadır ${ }^{20}$.

2. Yaş: Kanatlı hayvanlarda gastrointestinal fitaz aktivitesinde yaşla birlikte bir artış olmaktadır $^{7}$. Fitat fosforundan 4 haftalık yaştaki broylerlerin \% 20 civarında yararlandığ oranın 6 haftalık yaşta \% 50 düzeyine kadar ulaştı̆̆ tacı tavukların civcivlik dönemlerine göre fitat fosforundan daha iyi yararlandıkları ifade edilmektedir ${ }^{13}$.

3. Rasyondaki kalsiyum ve fosfor düzeyleri: Kanatlı hayvanlarda fitaz enziminin etkinliğinin belirlenmesinde, rasyondaki kalsiyum düzeyinin yanı sıra kalsiyum/fosfor oranı da önemli bir rol oynamaktadır. Rasyondaki yüksek kalsiyum düzeyi fitat fosforundan yararlanmayı olumsuz yönde etkilemektedir ve kalsiyumun olumsuz etkisine ilişkin üç mekanizma ileri sürülmektedir. Birinci mekanizma; kalsiyumun fitaz enzimi ile erimeyen kompleksler oluşturarak, fitatların hidrolize olmasını engellemesidir ${ }^{26}$. İkinci mekanizma; kalsiyumun barsak pH'sını etkileyerek, mikrobiyal fitaz aktivitesinde düşüşe yol açmasıdır ${ }^{13}$. Son mekanizma ise rasyondaki fazla kalsiyumun fitaz enziminin aktif bölgelerine bağlanarak, enzim aktivitesini baskılamasidır ${ }^{17}$. Bu nedenle broyler rasyonlarına fitaz ilavesi düşünüldügünde, enzimden maksimum düzeyde yararlanabilmek için rasyondaki kalsiyum seviyesinin \% 0.60 - \% 0.75 düzeyle- 
rine düşürülmesi gerektiği vurgulanmaktadır ${ }^{18}$. Ayrıca rasyondaki kalsiyum/fosfor oranının $2 / 1$ 'den daha yüksek olması durumunda, kanatlı hayvanların bağırsaklarında fitaz enzimine dirençli erimeyen penta-kalsiyum fitat kompleksinin oluştuğu ve böylece fitat sindiriminin olumsuz yönde etkilendiği belirtilmektedir ${ }^{13}$.

4. Rasyondaki vitamin $D_{3}$ düzeyi: Rasyondaki vitamin $\mathrm{D}_{3}$ düzeyinin yetersiz olmas1, fitat fosforunun sindirimini azaltmaktadır. Vitamin $\mathrm{D}_{3}$ ya da 1.25-dihidroksikolekalsiferol gibi vitamin $\mathrm{D}_{3}$ metabolitlerinin civcivlerde fitat fosforunun sindirilebilirliğinde \% 68 düzeyine kadar artış sağladığı bildirilmektedir ${ }^{6}$. Kanatlı rasyonlarına vitamin $\mathrm{D}_{3}$ ilavesiyle fitat fosforunun sindirilebilirliğindeki artış üç nedene bağlanmaktadır. Bunlar; intestinal fitaz sentezinde ya da aktivitesindeki artış, fitatların hidrolize olma oranındaki artış ve fosfor absorbsiyonundaki artıştır.

5. Rasyondaki selüloz düzeyi: Konuya ilişkin çalışmalar rasyondaki selülozun kalsiyumun kullanılabilirliğini modifiye etmek suretiyle kanatlı hayvanların fitat fosforundan yararlanmasını olumlu yönde etkilediğini göstermiştir. Selülozun bu etkisini sadece fermente olup fitatların kalsiyumu bağlama kapasitesini azaltarak değil, aynı zamanda fitatların hidrolize olma oranını artırarak gösterdiği ileri sürülmektedir ${ }^{26}$. Selülozun katyon değiştirme özelliği sayesinde, gastrointestinal kanalda katyonların konsantrasyonunu düşürerek fitatların hidrolizini artırdığı ifade edilmektedir ${ }^{1}$.

6. Yem maddelerinin türü: Farklı yem maddelerindeki fitatların, fitaz aktivitesine karş1 duyarlılıkları da oldukça farklıdır. Bu durum fitatların asidik pH'da çözünebilme kapasitelerine bağlıdır. Asidik pH'da yüksek çözünme kapasitesine sahip olan fitatlar, fitaz enziminin etkisiyle daha kolay hidrolize olmaktadır. Soya fasulyesi küspesindeki fitatların, susam küspesindekilere göre daha yüksek çözünme kapasitesine sahip oldukları ifade edilmektedir ${ }^{3}$. Ayrıca buğday, pirinç ve arpa gibi bazı tahılların fitaz aktivitesine sahip oldukları ve bu tahılların kanatlı rasyonlarında kullanılması durumunda fitatların hidrolizine büyük katkı sağladıkları belirtilmektedir ${ }^{23,24}$. Bu bağlamda buğday kepeği içeren rasyonla beslenen civcivlerdeki fitat sindiriminin, mısır-soya küspesi temeline dayanan rasyonla beslenen civcivlerden daha yüksek olduğu bildirilmektedir ${ }^{1}$.

7. Rasyona ekzojen fitaz ilavesi: Fitaz, fitik asiti inositol ve inorganik fosfora hidrolize ederek fosfor kullanılabilirliğinde ve kanatlı performansında artışa yol açan bir enzimdir.
Şekil 2'de fitaz enziminin etki mekanizması şematize edilmiştir. Fitazlar; hidroliz olayının inositolun hangi karbon atomundan başladığına göre 3-fitazlar (mikroorganizmalar tarafından üretilen fitazlar) ve 6-fitazlar (bitkiler tarafından üretilen fitazlar) olmak üzere 2 gruba ayrılırlar. Mikrobiyal fitazlar, bitkisel fitazların aksine daha geniş bir $\mathrm{pH}$ aralığında aktivitelerini korurlar ve böylece kanatlı hayvanların bezli mide ve taşlığında aktivite kaybına uğramazlar. Mikrobiyal fitazlar için optimum $\mathrm{pH}$ aralığının 2.57.5 , optimum sicaklığın ise $35-63{ }^{\circ} \mathrm{C}$ arasında olduğu ve bitkisel fitazlara göre gastrointestinal kanalda daha etkili oldukları bildirilmektedir ${ }^{27}$. Ticari olarak kullanılan mikrobiyal fitaz enzimleri daha çok Aspergillus niger, Aspergillus ficcum, Aspergillus oryzae gibi mantarlar tarafından üretilen enzimlerdir. Bakteri (Bacillus subtilis, Escherichia coli) ve mayalar (Saccharomyces cerevisiae) tarafindan da fitaz enzimi üretilmektedir. Aspergillus ficcum'un ürettiği enzim en yüksek fitaz konsantrasyonuna sahip iken, fitaz aktivitesi en yüksek olan enzim Aspergillus niger tarafından üretilmektedir. Ayrıca Aspergillus ficcum tarafindan üretilen fitaz enzimi diğer fitazlara göre daha termostabil yapıda olup, yemin peletlenmesi sirasinda önemli bir aktivite kaybına uğramamaktadır. Fitaz aktivitesi genellikle FTU olarak ifade edilmektedir. $37^{\circ} \mathrm{C}$ ve $\mathrm{pH} 5.5^{\prime}$ de $5.1 \mathrm{mmol}$ sodyum fitattan 1 dakikada $1 \mu \mathrm{mol}$ inorganik fosforu açığa çıkaran enzim miktarı bir ünite fitaz aktivitesi olarak tanımlanmaktadır ${ }^{8}$. Son yıllarda rekombinant DNA teknolojisindeki gelişmeler, ticari olarak kullanılan fitazların fonksiyonel özelliklerinde iyileşmeyle sonuçlanmıştır. Enzim teknolojisindeki gelişmelere parelel olarak; fitik asitin gerek kanatlı performans1 gerekse üretim maliyetleri ve özellikle de çevre üzerinde yol açtığı olumsuz etkileri önlemek amaciyla fitazın kanatlı hayvanların rasyonlarında kullanımı daha da yaygınlaşmıştır. Enzim kullanımın yaygınlaşmasına bu konuda yapılan bilimsel çalışmalardan alınan pozitif sonuçlar da katkı sağlamıştır.

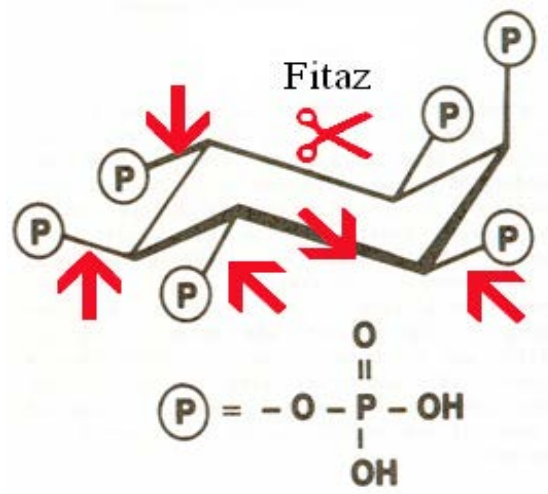

Şekil 2. Fitaz Enziminin Etki Mekanizması. 


\section{Broyler Rasyonlarında Fitaz Enzimi Kullanımına İlişskin Çalışmalar}

Kanatlı rasyonlarına eksojen fitaz ilavesine ilişkin ilk çalışma Nelson ve ark. ${ }^{14}$ tarafindan broylerler üzerinde yapılmıştır. Araştırmada; misır-soya küspesi temeline dayanan ve $\% 0.24$ oranında fitat fosforu içeren rasyonlara \% 0.4 düzeyinde Aspergillus ficcum kaynaklı işlem görmemiş fitaz katılmış ve broylerlerin canlı ağırlık kazancında \% 33.3 düzeyinde artış sağlanmıştır. Simons ve ark. ${ }^{21}$ düşük fosfor içeren broyler rasyonlarına mikrobiyal fitaz ilavesinin; canlı ağırlık kazancı, yem tüketimi ve yemden yararlanmayı önemli düzeyde iyileștirdiğini ve bu parametrelerde gözlenen iyileşmenin fitazın ilave düzeyi ile ilişkili olduğunu ileri sürmüşlerdir. Benzer bir çalışmada ${ }^{2}$ broyler rasyonlar1na farklı dozlarda fitaz ilavesinin $(125,250$ ve $500 \mathrm{FTU} / \mathrm{kg}$ yem) büyüme performansında sırasıyla \% 4.6, 6.4 ve 8.5 düzeylerinde artış sağladığ 0.27 ve 0.34 düzeylerinde kullanılabilir fosfor içeren broyler rasyonlarına yedi farklı dozda $(0$, 200, 400, 600, 800, 1000 ve $1200 \mathrm{FTU} / \mathrm{kg}$ yem) fitaz enzimi ilave etmişlerdir. Araştırmacılar, kullanılabilir fosfor düzeyleri farklı olan üç rasyonun da broylerlerin canlı ağırlık kazancı ve yem tüketiminde iyileşme sağladığını ancak bu etkinin kullanılabilir fosfor düzeyi en düşük olan grupta maksimum düzeye ulaştığını öne sürmüşlerdir. Düşük fosfor içeren broyler rasyonlarına eksojen fitaz ilavesiyle; fitat-mineral kompleksindeki fosforun serbest kalması sonucunda kullanılabilirliğinin arttığı, bunun da yem tüketimi ve yemden yararlanmayı iyileştirerek büyüme performansında artışa yol açtığı ileri sürülmektedir ${ }^{17}$. Enzim ilavesiyle broylerlerin büyüme performansında gözlenen artışa; inositol $^{21}$, nişasta ${ }^{11}$, protein ve amino asitlerin ${ }^{19}$ sindirilebilirliğinde meydana gelen artışların da katkı sağladığı belirtilmektedir.

\section{Yumurta Tavuğu Rasyonlarında Fitaz Enzimi Kullanımına İlişkin Çalışmalar}

Broylerler ile karşılaştırıldığında, yumurta tavuklarında fitaz enziminin etkisini araştıran çalışmaların sayısı daha azdır. Yumurta tavuklar1 üzerinde yapılan araştırmalarda; rasyona eksojen fitaz ilavesiyle fitat fosforunun biyoyararlanımında meydana gelen artışın, yem tüketimi, yumurta verimi ve yumurta ağırlığında iyileşmeyle sonuçlandığ bildirilmektedir ${ }^{9,16,25}$. Deniz ve ark. ${ }^{5}$ tarafindan yumurta tavukları üzerinde yapılan bir çalışmada; mısır soya temeline daya11 rasyonlar ile \% 10 düzeyinde DDGS içeren rasyonlara Escherichia coli kaynaklı yeni jenerasyon fitaz enzimi ilave edilmiştir (300 FTU/kg yem). Araştırmada fitaz enziminin yumurta tavuklarının performans, yumurta kalitesi, gübredeki fosfor ve nitrojen düzeyleri ile yem maliyeti üzerindeki etkileri belirlenmeye çalışılmıştır. Araştırmanın sonunda; gerek mısır soya temeline dayalı gerekse DDGS içeren rasyonlara mikrobiyal fitaz ilavesinin, yumurta tavuklarının performans ve yumurta kalitesine ilişkin parametrelerinde olumsuz bir etki oluşturmaksızin yem maliyeti ve gübredeki fosfor düzeyinde azalmaya yol açtığı saptanmıştır.

\section{Sonuç}

Kanatlı hayvanların rasyonları büyük oranda bitkisel kökenli yem maddelerinden oluşmaktadır. $\mathrm{Bu}$ yem maddelerindeki toplam fosforun önemli bir bölümü (\% 60-80) kanatlı hayvanlar tarafindan yeterince yararlanılamayan fitik asite bağlı fitat fosforu formundadır. Fitat fosforundan yararlanma; fitatların kaynağı, kanatlının yaşı, rasyondaki kalsiyum ve vitamin $\mathrm{D}_{3}$ düzeylerine bağlı olarak \% $0-50$ oranları arasında değişkenlik gösterebilmektedir. Fitik asit güçlü şelat oluşturma özelliği sayesinde; fosforun yanı sira yem maddelerindeki önemli mineralleri de (kalsiyum, çinko, bakır) bağlayarak, bu minerallerin kanatlı hayvanlar tarafindan kullanımını azaltmakta ya da tamamen engel olmaktadır. Fitik asit ayrıca yem maddelerindeki protein ve karbonhidratları da bağlayarak kanatlının bu besin maddelerinden yararlanmasını azaltmaktadır. Gerek endojen gerekse eksojen kaynaklı fitaz enzimi; fitatları inositol ve inorganik fosfora ayırarak, fitatların antinutrisyonel etkisini ortadan kaldırmaktadır. Endojen fitaz enziminin konsantrasyonu genç kanatlı hayvanlarda oldukça düşük olup, yaşla birlikte enzim aktivitesinde artış olmaktadır. Eksojen kaynaklı fitaz enziminin rasyonlara ilavesiyle; fitik asite bağl1 fosfor, kalsiyum ve çinko gibi mineraller ile protein, amino asitler ve nişasta sindirilebilirliğinde meydana gelen artışlar kanatlı performansında iyileşmeye yol açmaktadır. Ayrica eksojen fitaz ilavesiyle, mineral maddelerin biyoyararlanımlarında artış sağlanarak kanatlı gübresindeki düzeyleri düşürülmekte ve böylece çevre kirliliğinin önlenmesine katkıda bulunulmaktadır. 


\section{Kaynaklar}

1. Ballam, G.C., Nelson, T.S., Kirby, L.K., 1984. Effect of fiber and phytate source and of calcium and phosphorus level on phytate hydrolysis in the chick. Poultry Sci., 63, 333-338.

2. Broz, J., Oldane, P., Perrin-Voltz, A.H., Rychen, G., Schulze, J. And Nuches, C.S., 1994. Effect of supplemental phytase on performance and phosphorus utilization in broiler Chickens fed low phosphorus diet without addition of inorganic phosphorus. Brit. Poult. Sci., 35, 273-280.

3. De Boland, A.R., Gamer, G.B., O`Dell, B.L., 1975. Identification and properties of phytate in cereal grains and oil seed products. J. Agricul. Food Chem., 23, 1186-1189.

4. Denbow, D.M., Ravindran, V., Kornegay, E.T., Yi, Z., Hulet, R.M., 1995. Improving phosphorous availability in soyabean meal for broilers by supplemental phytase. Poultry Sci., 74, 18311842.

5. Deniz, G., Gezen, S.S., Kara, C., Gencoglu, H., Meral, Y., Baser, E., 2013. Evaluation of nutrient equivalency of microbial phytase in hens in late lay given maize-soybean or distiller's dried grains with solubles (DDGS) diets. Brit. Poult. Sci., 54, 494-502.

6. Edwards, H.M. Jr., 1993. Dietary 1, 25dihydroxycholecalciferolsupplementaion increases natural phytate phosphorus utilization in chickens. J. Nutr., 123, 567-577.

7. Edwards, H.M. Jr., Palo, P., Soonchaerenyıng, S., Elliot, M.A. 1989. Factors influencing the bioavailability of phytate phosphorus to chickens. In: SOUTHGATE, D., JOHNSON, I. and FENWICK, G.R. (Eds) Nutrient availability: Chemical and Biological Aspects, pp. 271-276.

8. Engelen, A.J., Van Der Heeft, E.C., Randsdorp, P.H.G., Smith, E.L.C. (1994) Simple and Rapid determination of phytase activity. J. Assoc. off Ana. Chem., 77, 760-764.

9. Gordon, R.W., Roland, S.R. 1997. Performance of commercial laying hens fed various phosphorus levels with and without supplemental phytase. Poultry Sci., 76, 1172-1177.

10. Kies, A.K., Van Hemert, K.H.F., Saucer, W.C., 2001. Effect of phytase on protein and amino acid digestibility and energy retention. World Poultry Sci. J., 57, 109-126.

11. Knuckles, B.E., Betschart, A.A., 1987. Effect of phytate and other myo-inositol phosphate esters on alpha-amylase digestion of starch. J. Food Sci., 52, 719-721.

12. N.R.C., 1994. In: Nutrient Requirements of Poultry, 9th ed., National Academy Press, Washington DC, USA.
13. Nelson, T.S., 1967. The utilization of phytate phosphorus by poultry: a review. Poultry Sci., 46: 862-871.

14. Nelson, T.S., Shieh, T.R., Wodzinski, R.J., Ware, J.H., 1971. Effect of supplemental phytase on the utilization of phytate phosphorus by chicks. J. Nutr., 101,1289-1294.

15. Pallauf, J., Rimbach, G., 1997. Nutritional significance of phytic acid and phytase. Arc. Anim. Nutr., 50, 301-319.

16. Punna, S., Roland, S.R., 1999. Influence of supplemental phytase on first cycle laying hens fed phosphorus deficient diets from day one of age. Poultry Sci., 78, 1407-1411.

17. Qian, H., Kornegay, E.T., Denbow, D.W., 1996. Phosphorus equivalence of microbial phytase in turkeys diets as influenced by calcium to phosphorus ratios and phosphorus levels. Poultry Sci., 75, 69-81.

18. Rama Rao, S.V., Reddy, V.R., Reddy, R.S., 1999. Enhancement of phytate phosphorus availability in the diets of commercial broilers and layers. Anim. Feed Sci. Tech., 79, 211-222.

19. Ravindran, V., Carbahug, S., Ravindran, G., Selle, P.H., Bryden, W.L., 2000. Response of broiler chickens to microbial phytase supplementation as influenced by dietary phytic acid and non-phytate phosphorous levels. II. Effects on apparent metabolisable energy, nutrient digestibility and nutrient retention. Brit. Poult. Sci., 41, 193-200.

20. Sebastian, S., Touch Burn, S.P., Chavez, E.R., 1998. Implications of Phytic acid and supplemented microbial phytase in poultry nutrition: a review. World Poultry Sci. J., 54, 27-47.

21. Simons, P.C.M., Versteegh, H.A.J., Jongbloed, A. W., Kemme, P.A., Slump, P., Bos, K.D., Wolters, M.G.E., Beudeker, R.F., Verschooor, G.J., 1990. Improvement of phosphorus availability by microbial phytase in broilers and pigs. Brit. J. Nutr. 64, 525-540.

22. Singh, P.K., Khatta, V.K., 2002. Phytase supplementation for economic and eco-friendly broiler production. J. Econ Physiol., 5, 117-121.

23. Singh, P.K., 2002. Utilisation of phytic acid in poultry diets. Poultry Planner, 3 (11): 17-19.

24. Singh, P.K., 2004. Wheat: An alternative of maize in poultry rations? Poultry Line, 4, 23-26.

25. Sohail, S.S., Roland, S.R., 2000. Influence of phytase on calcium utilization in commercial layers. J. Appl. Poultry Res., 9, 81-87.

26. Wise, A., 1983. Dietary factors determining the biological activity of phytase. Nutr. Abstr. Rev., 53: 791-806.

27. Wodzinski, R.J., Ullah, A.H.J., 1996. Phytase. Adv. Appl. Microbiol., 42, 263-303. 
